\title{
DETERMINANTS OF EFFECTIVENESS REPAYMENT APPS AT P2P LENDING PLATFORM DURING COVID 19 PANDEMIC IN INDONESIA
}

\author{
Florentina Kurniasari ${ }^{1}$ \\ Technology Management Department, \\ Universitas Multimedia Nusantara \\ florentina@umn.ac.id \\ Prio Utomo ${ }^{2}$ \\ Technology Management Department, \\ Universitas Multimedia Nusantara \\ prio.utomo@umn.ac.id
}

Received on 4 June 2021

Approved on 19 June 2021

\begin{abstract}
The advance of technology development today brings an innovation in the financial industries all across the world, including in Indonesia. The financial technology continues to emerge from the sector of payment, investment and loans online or as we are familiar with the term P2P Lending platform. But, the growth of this business had a challenge when the Covid-19 Pandemic hit the country in the early 2020. The P2P lending platform experienced the first highest default rate due the difficulties of the SME's as its major customers' in repaying their loans. The purpose of this research is to analyze the determinants of effectiveness repayment apps for ultra-micro segment on P2P platform in Indonesia. As a quantitative research, primary data were collected through questionnaire answered by 133 respondents who were borrower of the $\mathrm{P} 2 \mathrm{P}$ lending platform. The data collection was furthered processed statistically using Structural Equation Method (SEM). The study showed that the repayment decision had significantly influenced by perceived usefulness, perceived ease of use, perceived risk and information quality. Information quality itself had the highest influenced among others.
\end{abstract}

Keywords: Perceived Usefulness; Perceived Ease of Use; Information Quality; Perceived Risks; Repayment Decision; Repayment Apps

\section{INTRODUCTION}

\subsection{Research Background}

The rapid advancement of knowledge and technology made changes in all aspects of businesses included in the financial system. Innovation in financial technology gave customers more alternatives in doing their financial transactions in more efficient and effective ways. The advance of information technology has encouraged the increase of innovation in many business and financial sectors. Financial technology is an innovative digital financial technology that offers financial services using information technology. As a new platform, financial technology offers more than simplifying financial transaction, minimizing cost and increasing financial services (Lee \& Shin, 2018). Peer-to-Peer Lending (P2P lending) is a form of crowdfunding without involving any financial institution as the intermediaries (Cinca et al., 2015) using an online platform (Ritter et al., 2009). The P2P 
lending platform offers flexibility to both parties: lenders and borrowers (Meng, 2016). The lenders, as investors, expect a higher return from their investment in a P2P lending platform. Meanwhile, the borrowers can take advantage of the low transaction cost. There are some risks of P2P lending, such as: uncertainty, anonymity, lack of control between lender and borrower, and potential opportunism since the lender and borrower do not know each other (Chen et al., 2014). Previous study has explained that the main risk of P2P lending activities is the risk of incoming information asymmetry among lenders, borrowers and intermediaries (Meng, 2016).

The financial technology is expected to fill the gap of financing needs and increase financial inclusion for Indonesians who were unbankable but had potential business. The financial technology could be seen as an alternative source of financing, especially for the ultra-micro segments to grow their business. The ultra-micro segments are characterized by their low daily income sales, doing business in densely populated housing areas and having simple self-owned trading business. In the year 2018, the total financial technology market in Indonesia reached US\$22 million with increasing rate at $16.3 \%$ yearly, in which lending occupied $31 \%$ of the total industry (Fintechnews.sg, 2018). Therefore, there is a huge potential market for P2P lending platforms in Indonesia

With the growing of P2P lending platforms, customers were enjoying to apply the loan in simple procedures without any obligations to provide collaterals. The data shown in the following table showed that in the three years in a row, there was an increasing growth of Small Medium Enterprise (SME's) in Indonesia, especially in Micro and Small segments, who were the major customers of the P2P lending platform.

Table 1. Percentage of SME's Credit in Indonesia for the year 2016-2018 (in \%)

\begin{tabular}{|c|c|c|}
\hline Year & Micro Segment Credit & Small Segment Credit \\
\hline 2016 & $24,50 \%$ & $29,80 \%$ \\
\hline 2017 & $24,80 \%$ & $29,90 \%$ \\
\hline 2018 & $25,40 \%$ & $30,10 \%$ \\
\hline
\end{tabular}

Source: Bank Indonesia (2019)

Referred to the Ministry of Finance Regulation No. 22/ PMK.05/2017, micro financing was a financing facilities given to the micro business segment with the maximum loan plafond was ten million rupiahs and the maximum repayment was one year. Indonesian government realized that the SME's sectors played an important role in supporting the country's economic growth. Some of the SME's function in supporting economic growth including: created job opportunities; handled the poverty issues or income disparities, had contribution of $59.08 \%$ of GDP with the growth rate at $6,4 \%$ annually with the export volume reached at $14.06 \%$ from the total national export. Indonesian government committed to increase the financial inclusion by providing banking and financial access to all people. Therefore, the existence of the financial technology (FinTech) that could provide credit and loan facilities was expected to assist the government reached that goal. The next table showed the profile and growth of FinTech in Indonesia (in Rupiahs): 
Table 2. Profile and FinTech Growth in Indonesia (as December 30th, 2019)

\begin{tabular}{|l|c|c|}
\hline Description & Java Island & Outside \\
\hline Accumulated Loan Disbursement (in Rupiahs) & 75,71 Trillion & 12,67 Trillion \\
\hline Accumulated Borrower Account & 16,94 Million & 3,5 Million \\
\hline Accumulated Lender Account & 5,08 Hundred & 1,04 Hundred \\
\hline Outstanding Loan & & 13,52 Trillion \\
\hline Success Rate 90 Days & \\
\hline Number of Licensed FinTech & $162 \%$ \\
\hline
\end{tabular}

Source: Otoritas Jasa Keuangan (2019)

Table 2 showed that there was a higher ability to pay from the borrower from both micro and small segments. The higher repayment ability rate (principal loan and interest) was mostly affected by the success of the borrower in doing their businesses using the loan from the $\mathrm{P} 2 \mathrm{P}$ lending platform.

The financing industries faces a biggest challenge when the Corona virus (Covid 19) was hit Indonesia in early 2020. The government took some strategic action to reduce the spread of the virus by issuing some rules and regulation such as: The Government Regulation (PP No.21, 2020) and Presidential Instruction (Keppres No.11, 2020). The regulation gave the guidance for the government offices across the country to implementing PSBB (Social Restriction in Large Scale). The PSBB rules prohibited the people to gather in crowd, and the government limited the people interaction in public, including: in school, malls, or in the religious places. This policy mostly hit the informal workers who were most of them worked in the SME's industries. The current data released by the Ministry of Cooperatives and SME's Republic of Indonesia showed that around 58.97 million SMEs had experience some difficulties in production and marketing during the Covid-19 pandemic. The business problem faced by SMEs had a significant effect into the P2P lending platform. The update data release in May $30^{\text {th }}, 2020$ stated that there was a declining average of repayment performance until 90 days after the due date from $96.02 \%$ into $93.55 \%$. The data showed that many borrowers of the P2P lending who are majority involved in SMEs industry also had difficulties in running their business and in the same time had difficulties in repaying their loan at the committed time.

In responding this current situation, the Indonesian government released some policy to supporting the SMEs as the backbone of the Indonesian economy. The Indonesian Financial Services Authority released Regulation No.11/POJK.03/2020 as the National Economic Stimulus as a Countercyclical Policy Impact of the Spread of Coronavirus Disease 2019). This regulation stated that the development of the spread of the Corona virus disease 2019 (COVID-19) has a direct or indirect impact on the performance and capacity of debtors, including micro, small and medium business (MSME), which could potentially disrupt banking performance and the stability of the financial system, which may further affect economic growth. Therefore, an economic stimulus policy is needed as a countercyclical impact of the spread of COVID-19. This regulation was valid for all financial sectors including formal banks, and also P2P lending platform. Some policy to assist the SME's covered the reducing of the interest rate, extending the repayment deadline and financing restructuring adjusted with the borrower abilities. The P2P lending must also follow this government regulation and in the same time initiate an innovative strategy such as 
introducing the Repayment Application (repayment apps) to assist the borrower in repaying their loan.

The objective of this study was to analyze the determinants of effectiveness repayment apps at one of biggest P2P lending platform (namely: MODALKU) during the Covid-10 pandemic in Indonesia.

\subsection{Literature Review}

\subsubsection{Financial Technology (Fintech)}

Financial technology is defined as mobile based technology to increase financial system efficiency (Kim et al., 2015) and a new type of information technology-based financial services (Lee \& Shin, 2018). The advanced of digital technology was be able to change the current business model and in the same time create values by taking internet to do some changes (Walchek, 2015). The information technology was proven to change people's way of life since social interaction networking and relationship was interconnected with internet and technology (Lim, 2003). Fintech is an innovation business model in the financial services which created from the rising of sharing economy system, the loosen of government regulation (Blohm, 2013).

\subsubsection{P2P Lending Platform}

$\mathrm{P} 2 \mathrm{P}$ lending is defined as all lending and borrowing activities among individuals using a technology platform without any intervention from a traditional financial institution (Lee \& Shin, 2018; Ritter et al., 2009) and related to the internet-based financing platform (Stern et $a l ., 2017)$. The $\mathrm{P} 2 \mathrm{P}$ lending model involved borrowing and lending activities using digital technology platform (Meng, 2016), offered unbundling financial services (Chen, 2014) and act as intermediary that connected the lenders and the borrowers (Schierz, 2010). The P2P lending platform analyze data and information both from the lender and borrower to control the risk, set-up the maximum loan nominal amount, the loan duration and repayment scheme (Khosravi and Hussin, 2014).

\subsubsection{Ultra-Micro Segment}

Indonesia is renowned for its large scale microfinance sector, with over than 50 million small medium enterprises (SMEs), representing some 97\% of all enterprises and contributing no less than 30\% of GDP growth in 2012 (Lim, 2003). However, many of these do not have adequate access to the bank financing they need to grow their businesses, particularly in rural areas. Most micro lending has been located in the urban areas of Java and Sumatra, where the Indonesian population is concentrated.

\subsubsection{Technology Acceptance Model (TAM)}

Technology Acceptance Model (TAM) was a model that could be used to analyze which factors influence people in receiving the information and adopting the new technology. TAM introduced by Venkatesh (2009) to measure the individual ability to adopt and accept the new technology. TAM concept focused more on two factors which refered to perceived usefulness dan perceived ease of use (Venkatesh, 2009). Later, this theory was further developed into Unified Theory of Acceptance and Use of Technology (Phonthanukitithaworn, 2016). Some factors included the Perceived Usefulness, Perceived Ease of Use, Perceived Risk and Information Quality (Egbunike, et. al, 2018). 


\subsubsection{Perceived usefulness}

Perceived usefulness defined as user assumption that the technology was able to assist in completing the works (Davis, 1989). Meng (2016) stated that individual would use the new technology only if gave positive contribution to the working performances. Venkatesh (2009) explained that perceived usefulness was a main factor in individual usage intention in using the new technology. Davis (1989) in his theory mentioned that perceived usefulness could be used to measure how far a user believed in specific application to increase his work performances. There would be a positive action if user gained some benefit while using that application (Gefen et al., 2003). Alarcon-del-Amo et al. (2014) explained that perceived usefulness had a positive effect into attitude and continuance intention (Liébana-Cabanillas et al., 2018; Chawla \& Joshi, 2018; Lee et al., 2015; Shipps \& Phillips (2013).

\subsubsection{Perceived ease of use}

Perceived ease of use defined as an easiness in using and applying the technology (Venkatesh, 2009). If individual believed that the usage of new technology application was less effort and problem free, the customers were willing to adopt the technology easily (Lim, 2003). Gefen, et al. (2003) explained that perceived ease of use had direct and indirect effect in using the new application. Davis (1989) also explained that the perceived ease of use referred to a condition which a user was able to use the technology at less effort by maximizing the feature in that application. Mwiya et al. (2017) and Alarcon-del-Amo et al. (2014) mentioned that ease of use had a significant effect into attitude. Perceived ease of use also had a positive influence for users in using the application (Liébana-Cabanillas F. et al., 2018; Lee et al., 2015; Shipps \& Phillips, 2013).

\subsubsection{Information Quality}

Mwiya et al. (2017) stated that information quality could be measured with the quality content of the information system. Alarcon-del-Amo et al. (2014) said the information quality was the function related with the value of information output of a system. A good information quality would bring customer trust in using the technology. Shipps \& Phillips (2013) mentioned there was three main dimension of information quality, including: accuracy, timeliness and relevancy.

\subsubsection{Perceived Risks}

Each customer had an individual perception about all risks related in using the new technology Liébana-Cabanillas F. et al. (2018). Perceived risk defined as individual perception in anticipating risks associated with the products or services consumption Lim (2003). Shipps \& Phillips (2013) added that perceived risk represented individual perception about the potential negative in the processing usage of products and services. Mwiya et al. (2017) stated that individual less interested in adopting higher risk platform.

\subsection{Repayment Decision}

The borrower decision in repaying the loan referred to actual condition in applying the system (Davis,1989). Once the borrower felt comfortable in using the application, they will decide to use it. The actual technology usage referred to the familiarity or the frequency in using the application. 


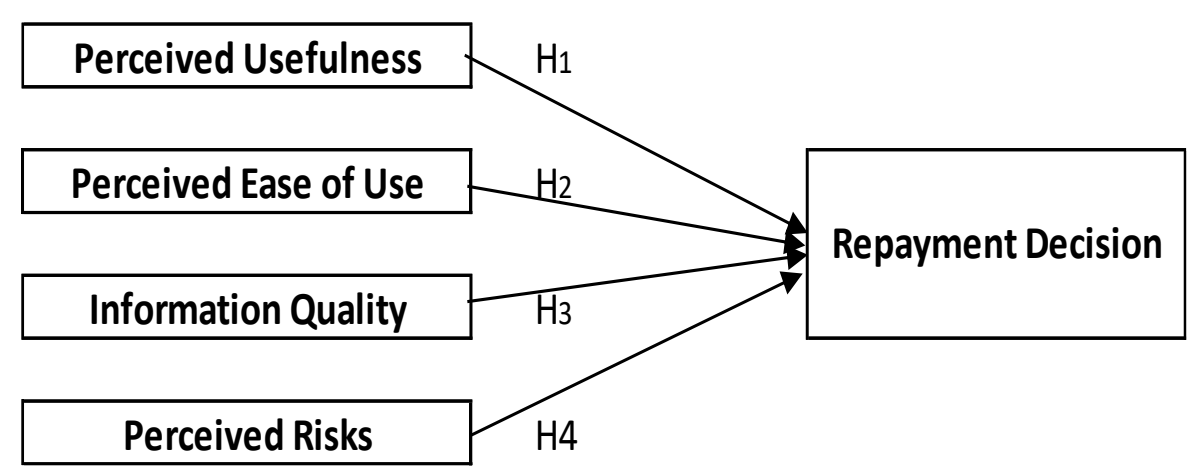

Figure 1. Research Theoretical Framework

Source: Researcher Data Analysis (2020)

Based on the proposed framework, the study was being able to develop some hypotheses as follows:

$H_{1}$ : Perceived Usefulness has a positive effect on Repayment Decision for ultramicro segments in Indonesia's P2P lending platforms. The perceived usefulness was the major factor in developing trust in acquiring and using the new technology which would assist the borrower in repaying the loans (Bachmann et al., 2011).

H2: Perceived Ease of Use has a positive effect on Repayment Decision for ultramicro segments in Indonesia's P2P lending platforms. Eisingerich \& Bell (2008) stated that the perceived ease of use created borrower trust if the borrower felt easy in using the new application.

H3: Information Quality has an influence on Repayment Decision for ultra-micro segments in Indonesia's P2P lending platforms. Lenders in P2P lending platforms look for a complete and clear information about their loan status, the interest rate, the duration of payment and any other issues. The smaller nominal of loanable funds shows the higher successful rate of loan repayment (Zhang et al., 2017). The longer the duration of repayment, the higher the default rate (Zhang et al., 2017). Higher interest rate gives higher return and higher risk associated with the default rate (Meng, 2016).

H4: Perceived Risks has a positive influence on Repayment Decision for ultramicro segments in Indonesia's P2P lending platforms.

Lower risk platform would develop the customer trust easier (Chen \& Han, 2012). Borrowers in P2P lending platforms look for safety protection, which is measured by sufficient security to protect the user, safety transactional information and secured financing transaction (Meng, 2016). The borrower trust was developing if the platform would be able to deliver the usefulness, the easiness of use about the platform and in the same time giving secure feeling or less risky in accessing the new technology

\subsection{Repayment Application Technology (the Worm)}

As one of the biggest P2P lending platform in Indonesia, MODALKU started to create an innovative strategy during the Covid-19 pandemic. The company committed to support the government policy in issuing the economic stimulus for the SMEs and in the same time, assist the SME's as its major borrowers to be able in running the business and finally fulfil their financial obligation to repaying their loan. The features in the Repayment Apps covered some specific programs, such as:

1. Credit Simulation: With this feature, the borrowers were able to get information about the calculation and estimated loan that can be applied adjusted with the borrower capabilities. 
2. Repayment Submission: was an application to extend the repayment period in the agreed specific time adjusted with the borrower financial abilities.

3. Profile: borrowers were able to access the update profile and loan application data.

4. History: this feature would showed all the information and history of loan credit extension and also the loan repayment approval status (approved or rejected).

All application data would be stored in MODALKU database and could be accessed through Repayment website. The website would allow the P2P lending platform in monitoring and managing the loan repayment scheme application and finally made a decision to approve or reject the application. The flow of repayment loan extension application process can be explained as follows:

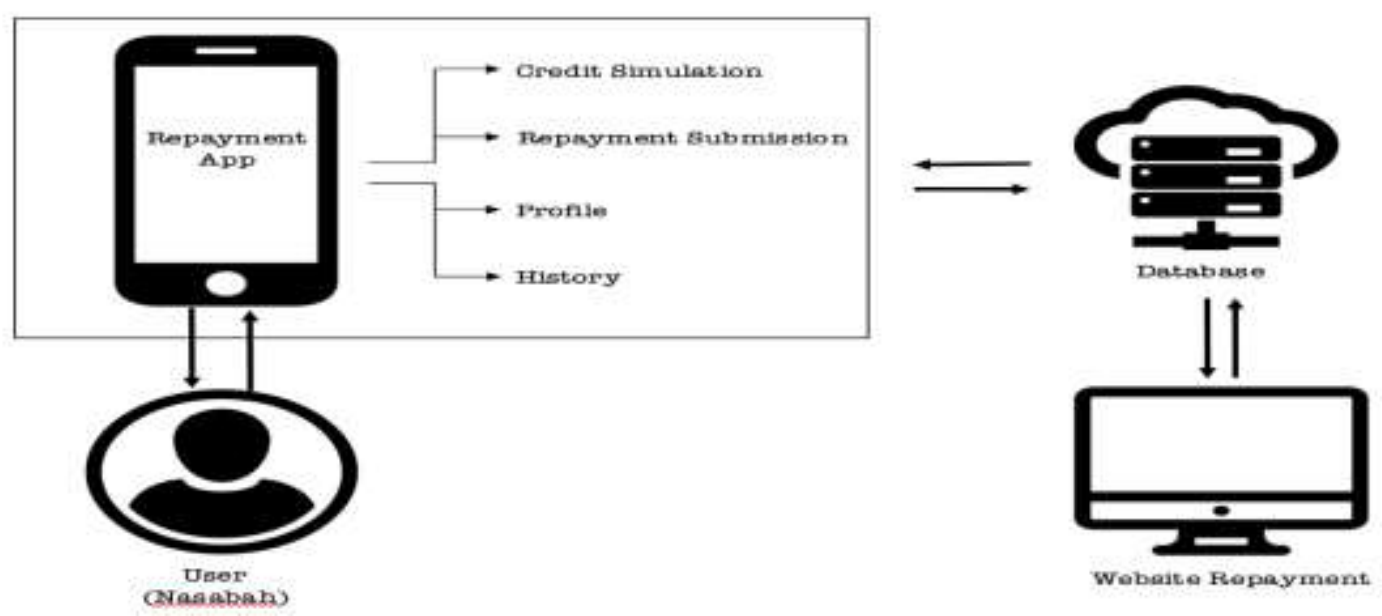

Source: Kurniasari F, et.al (2020)

Figur 2. The Flow of Repayment Loan Extension Application Process

\section{RESEARCH METHODOLOGY}

This research was a hypotheses testing study to describe the causality among the repayment decision as dependent variable with independent variables consisted of: perceived usefulness, perceived ease of use, information quality and perceived risks (Cooper \& Schindler, 2014). This study distributed 113 respondents who were P2P lending platform (MODALKU) ultra-micro segments borrowers who were resided in Jakarta areas and familiar with the new Repayment Apps (=the Worm) during the Covid 19-pandemic started at 2020. As a quantitative research, the respondents were asked to answer close-ended questions with 1-5 Likert scale (Nunnaly, 1978). The first part of the questionnaires consists with the demographic questions and the second part of the questionnaires consist with the research questions. The perceived usefulness (PU) variable was indicated by three indicators, namely: the apps would help the borrower in managing and keep track the loan (PU1), the Repayment apps was useful for the borrower (PU2) and the using the apps would make the borrower able to check the loan status quickly/rapid transaction (PU3) (Mwiya et al., 2017). Mwiya et al. (2017) mentioned that the perceived ease of use (PE) was reflected into three indicators, such as: the easiness to operate (PE1); had a flexibility to use (PE2) and the features are simple and understandable (PE3). The information quality variable (IQ) was explained by three indicators, including: the relevancy of content with the current situation (IQ1), the accuracy information (IQ2) and the complete or trusted information (IQ3) (Mwiya et al., 2017). Oliver (1993) mentioned that perceived risks (PR) could be measured into two indicators: there are 
some risks when using the apps (PR1) and the repayment apps had to ensure the data security (security) (PR2). The Repayment decision (RD) according Bhattacherjee (2001) could be explained with the two indicators, such as: I plan to use the apps soon (RD1) and I am sure I will use the apps in repaying my loan (RD2). All the primary data further tested statistically using Structural Equation Model with Lisrel 8.80 software. Objek yang diteliti dalam penelitian ini adalah karyawan perusahaan ritel yang beroperasi di wilayah Tangerang, Tangerang Selatan, Jakarta, dan Bogor yang aktivitas pencatatannya telah menggunakan Sistem Informasi Akuntansi (SIA) mulai dari pencatatan transaksi sehari-hari, penyusunan laporan keuangan sampai pengambilan keputusan. Responden dalam penelitian ini merupakan karyawan bagian keuangan dan accounting yang bekerja dengan menggunakan software akuntansi seperti Oracle, Zahir, Accurate, Jurnal.id dan sebagainya. Periode penelitian adalah tahun 2020.

\section{RESULTS AND DISCUSSION}

Demographic data explained the profile of the respondents; $73.5 \%$ respondents were emale with the majority age being 30-39 years old (63.3\%); 62\% respondents had monthly income at between 1-4.9 million Rupiah. 99\% respondents took SMEs loan financing with $71.30 \%$ loan duration period was less than a year with average loan nominal around fivemillion Rupiahs (47.90\%). Most of them (86\%) found that Covid 19 had a siginificant effect in loan repayment and $33 \%$ were asking for temporary repayment holiday; $26.6 \%$ were looking for extention of repayment period; and $20.2 \%$ were asking for the flexibility of loan nominal repayment adjusted with their financial capabilities. The mean value analysis showed that for all independent variables, Information Quality (IQ) had the highest mean value of 4.30 and the Perceived Usefulness (PU) had the lowest mean value of 3.64

The average mean value of perceived usefulness variable as it stated in the table 3 and further explained in the figure 3, was 3.64, in which PU3 had the lowest mean value and PU1 had the highest mean value. This data showed that the using the Repayment apps provided by the P2P lending platform would assist them in better manage and keep track of their existing loan without necessary contact with the P2P lending platform office or sales agent.

Table 3. Mean Value of Perceived Usefulness Indicators

\begin{tabular}{|c|c|c|c|c|c|c|}
\hline SCALE & $\mathbf{1}$ & $\mathbf{2}$ & $\mathbf{3}$ & $\mathbf{4}$ & $\mathbf{5}$ & MEAN \\
\hline \multirow{2}{*}{ PU1 } & 0 & 0 & 35 & 46 & 32 & \multirow{2}{*}{3.97} \\
\cline { 2 - 6 } & $0 \%$ & $0 \%$ & $31 \%$ & $41 \%$ & $28 \%$ & \\
\hline \multirow{2}{*}{ PU2 } & 3 & 14 & 29 & 52 & 15 & \multirow{2}{*}{3.55} \\
\cline { 2 - 6 } & $3 \%$ & $12 \%$ & $26 \%$ & $46 \%$ & $13 \%$ & \\
\hline \multirow{2}{*}{ PU3 } & 2 & 13 & 39 & 56 & 3 & \multirow{2}{*}{3.40} \\
\cline { 2 - 6 } & $2 \%$ & $12 \%$ & $35 \%$ & $50 \%$ & $3 \%$ & \multirow{2}{*}{ A.64 } \\
\hline \multicolumn{7}{|c|}{} \\
\hline
\end{tabular}

Source: Researcher Data Analysis (2020) 


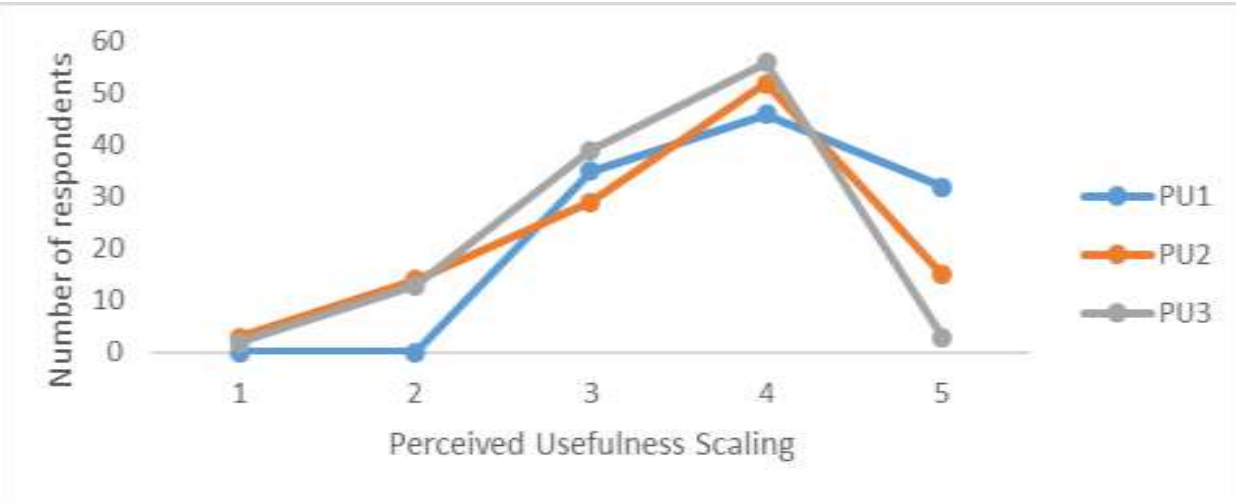

Figure 3. Perceived Usefulness Scalin

Source: Researcher Data Analysis (2020)

The average mean value of perceived ease of use variable as it stated in the table 4 and further explained in the figure 4, was 4.01, in which PE2 had the highest mean value and PE1 had the lowest mean value. This data showed that the majority of borrowers agreed that the repayment apps was flexible to use.

Table 4. Mean Value of Perceived Ease of Use Indicators

\begin{tabular}{|c|c|c|c|c|c|c|}
\hline SCALE & $\mathbf{1}$ & $\mathbf{2}$ & $\mathbf{3}$ & $\mathbf{4}$ & $\mathbf{5}$ & \multirow{2}{*}{ MEAN } \\
\hline \multirow{2}{*}{ PE1 } & 0 & 2 & 45 & 32 & 34 & \multirow{2}{*}{3.87} \\
\cline { 2 - 6 } & $0 \%$ & $2 \%$ & $40 \%$ & $28 \%$ & $30 \%$ & \\
\hline \multirow{2}{*}{ PE2 } & 0 & 5 & 23 & 33 & 52 & \multirow{2}{*}{4.17} \\
\cline { 2 - 6 } & $0 \%$ & $4 \%$ & $20 \%$ & $29 \%$ & $46 \%$ & \\
\hline \multirow{2}{*}{ PE3 } & 0 & 2 & 32 & 43 & 36 & \multirow{2}{*}{4.00} \\
\cline { 2 - 6 } & $2 \%$ & $2 \%$ & $28 \%$ & $38 \%$ & $32 \%$ & \multirow{2}{*}{ Average } \\
\hline \multicolumn{7}{|c|}{} \\
\hline
\end{tabular}

Source: Researcher Data Analysis (2020)

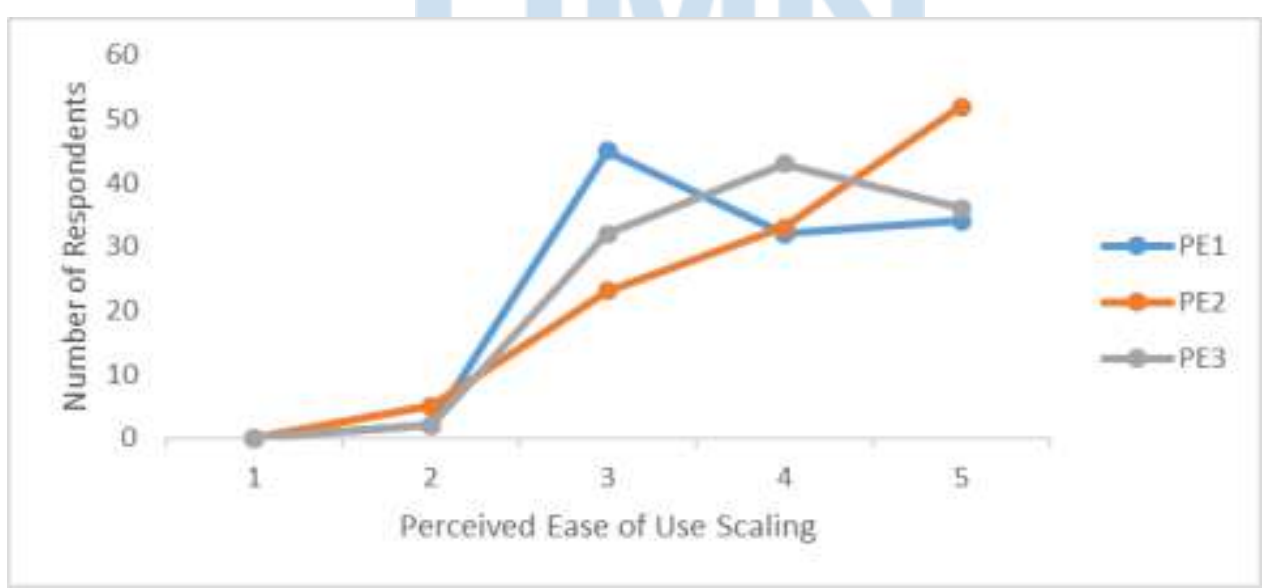

Figure 4. Perceived Ease of Use Scaling

Source: Researcher Data Analysis (2020)

Meanwhile, the average mean value of information quality variable as it stated both in the table and figure 5, was 4.30, in which IQ1 had the highest mean value (4.33) and both IQ 2 and IQ 3 had the same mean value of 4.29. This data showed that the borrowers belief that 
all the information and its content provided in the repayment apps was relevance with the current situation. The information quality had the highest mean among all the independent variables used in this research.

Table 5. Mean Value of Information Quality Indicators

\begin{tabular}{|c|c|c|c|c|c|c|}
\hline SCALE & 1 & 2 & 3 & 4 & 5 & MEAN \\
\hline \multirow{2}{*}{ IQ1 } & 1 & 3 & 15 & 33 & 61 & \multirow{2}{*}{4.33} \\
\hline & $1 \%$ & $3 \%$ & $13 \%$ & $29 \%$ & $54 \%$ & \\
\hline \multirow{2}{*}{ IQ2 } & 0 & 2 & 12 & 50 & 49 & \multirow{2}{*}{4.29} \\
\hline & $0 \%$ & $2 \%$ & $11 \%$ & $44 \%$ & $43 \%$ & \\
\hline \multirow{2}{*}{ IQ3 } & 0 & 0 & 12 & 56 & 45 & \multirow{2}{*}{4.29} \\
\hline & $0 \%$ & $0 \%$ & $11 \%$ & $50 \%$ & $39 \%$ & \\
\hline \multicolumn{6}{|c|}{ Average } & 4.30 \\
\hline
\end{tabular}

Source: Researcher Data Analysis (2020)

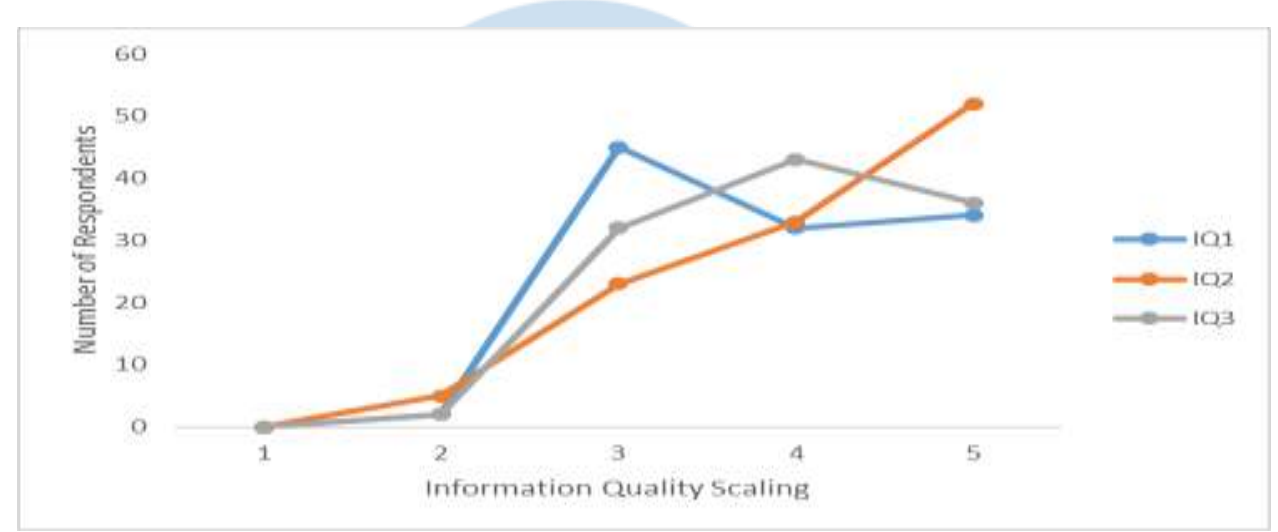

Figure 5. Information Quality Scaling

Source: Researcher Data Analysis (2020)

The PR1 had the highest mean value and PR2 had the lowest mean value as perceived risks indicators. The average mean value of perceived risks variable as it stated both in the table and figure 6 , was 3.92. It meant that the borrowers realized that there was some risk related with the security issues when using the repayment apps.

Table 6. Mean Value of Perceived Risks Indicators

\begin{tabular}{|l|l|l|l|l|l|l|}
\hline \multirow{2}{*}{ SCALE } & $\mathbf{1}$ & $\mathbf{2}$ & $\mathbf{3}$ & $\mathbf{4}$ & $\mathbf{5}$ & \multirow{2}{*}{ MEAN } \\
\hline \multirow{2}{*}{ PR1 } & 0 & 0 & 42 & 26 & 45 & \multirow{2}{*}{4.03} \\
\cline { 2 - 6 } & $0 \%$ & $0 \%$ & $37 \%$ & $23 \%$ & $40 \%$ & \\
\hline \multirow{2}{*}{ PR2 } & 1 & 3 & 34 & 52 & 23 & \multirow{2}{*}{3.82} \\
\cline { 2 - 5 } & $1 \%$ & $3 \%$ & $30 \%$ & $46 \%$ & $20 \%$ & \multirow{3}{*}{$\mathbf{3 . 9 2}$} \\
\hline \multirow{2}{*}{ Average }
\end{tabular}

Source: Researcher Data Analysis (2020) 


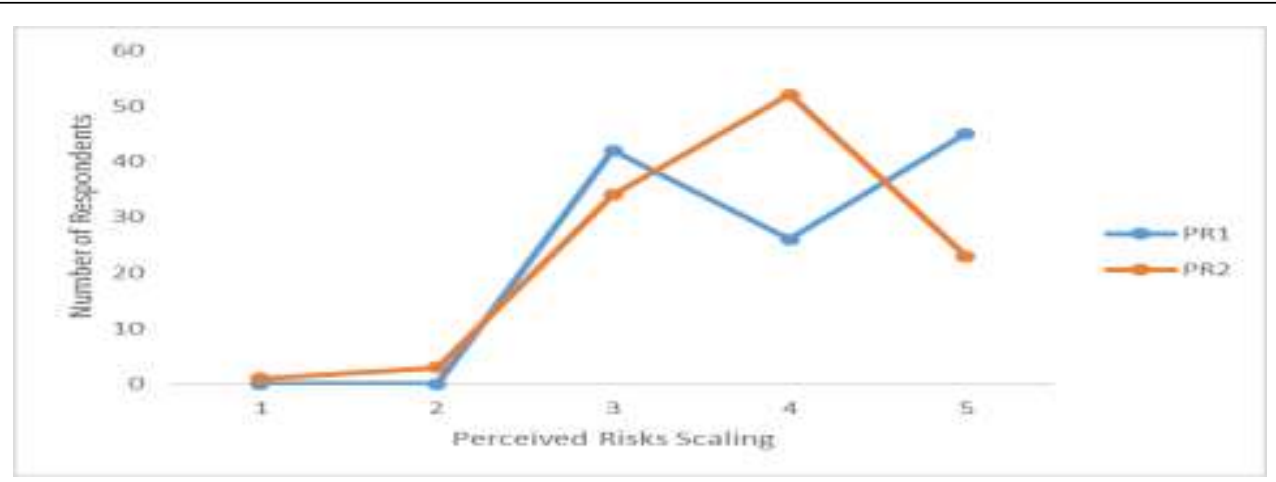

Figure 6. Perceived Risks Scaling

Source: Researcher Data Analysis (2020)

In the repayment decisions variables, RD1 indicator had the lowest mean value (4.48), and RD2 had the highest mean value of 4.51. Meanwhile the average mean value for both indicators was 4.50. The data showed that all borrowers were strongly agree to use that the repayment apps in managing and settling their loans in P2P lending platform.

Table 7. Mean Value of Repayment Decision Indicators

\begin{tabular}{|l|l|l|l|l|l|l|}
\hline \multirow{2}{*}{ SCALE } & $\mathbf{1}$ & $\mathbf{2}$ & $\mathbf{3}$ & $\mathbf{4}$ & $\mathbf{5}$ & MEAN \\
\cline { 2 - 7 } & 0 & 0 & 0 & 59 & 54 & \multirow{2}{*}{4.48} \\
\hline \multirow{2}{*}{ RD2 } & $0 \%$ & $0 \%$ & $0 \%$ & $52 \%$ & $48 \%$ & \\
\cline { 2 - 7 } & 0 & 0 & 0 & 55 & 58 & \multirow{2}{*}{4.51} \\
\hline \multirow{2}{*}{ Average } & $0 \%$ & $0 \%$ & $49 \%$ & $51 \%$ & \\
\hline
\end{tabular}

Source: Researcher Data Analysis (2020)

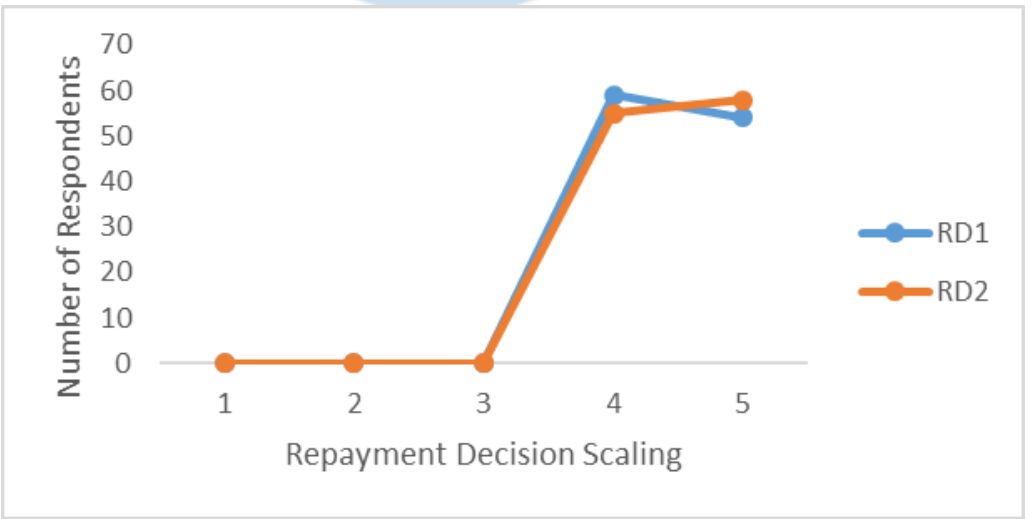

Figure 7. Repayment Decisions Scaling

Source: Researcher Data Analysis (2020)

Using Pearson correlation method and pre-test, it found that the critical value of $t>$ 0.671, showed that all indicators had strong correlation. Reliability test using Cronbach's Alpha coefficient showed the number of 0.911 , which meant that this research is valid. To measure the fitness of the research model, the Confirmatory Factor Analysis (CFA) was used. Analysis toward the structured model were used to see the correlation toward the latent variable. The table 8 showed that only AGFI indicator had value less than $<0.90$ and there were perfect theories in this research. The table 9 showed the value of R Square and Adjusted $\mathrm{R}$ Square for each variable: 
Table 8. Design Summary for Goodness for Fit Testing Model

\begin{tabular}{|c|c|c|c|}
\hline GOF Indicator & EstimatedValue & Testing Result & Conclusion \\
\hline \multicolumn{4}{|c|}{ Absolute Fit Value } \\
\hline GFI & $\mathrm{GFI} \geq 0.90$ & 0.90 & Good Fit \\
\hline RMSEA & RMSEA $<0.08$ & 0.048 & Good Fit \\
\hline \multicolumn{4}{|c|}{ Incremental Fit Value } \\
\hline NNFI & $\mathrm{NNFI}>0.90$ & 0.98 & Good Fit \\
\hline NFI & $\mathrm{NFI}>0.90$ & 0.97 & Good Fit \\
\hline AGFI & AGFI $>0.90$ & 0.89 & Marginal Fit \\
\hline RFI & RFI $>0.90$ & 0.96 & Good Fit \\
\hline IFI & $\mathrm{IFI}>0.90$ & 0.98 & Good Fit \\
\hline
\end{tabular}

Source: Data Analysis using LISREL 8.80

Table 9. R-Square and Adjusted R-Square

\begin{tabular}{llll}
\hline Variables & $\begin{array}{l}\text { R- } \\
\text { Square }\end{array}$ & $\begin{array}{l}\text { Adjusted } \\
\text { Square }\end{array}$ & R- \\
\hline Perceived Usefulness & 0.005 & -0.005 \\
Perceived Ease of Use & 0.361 & 0.334 \\
Information Quality & 0.862 & 0.783 \\
Perceived Risks-Free & 0.040 & 0.031 \\
\hline
\end{tabular}

Source: Data Analysis using LISREL 8.80

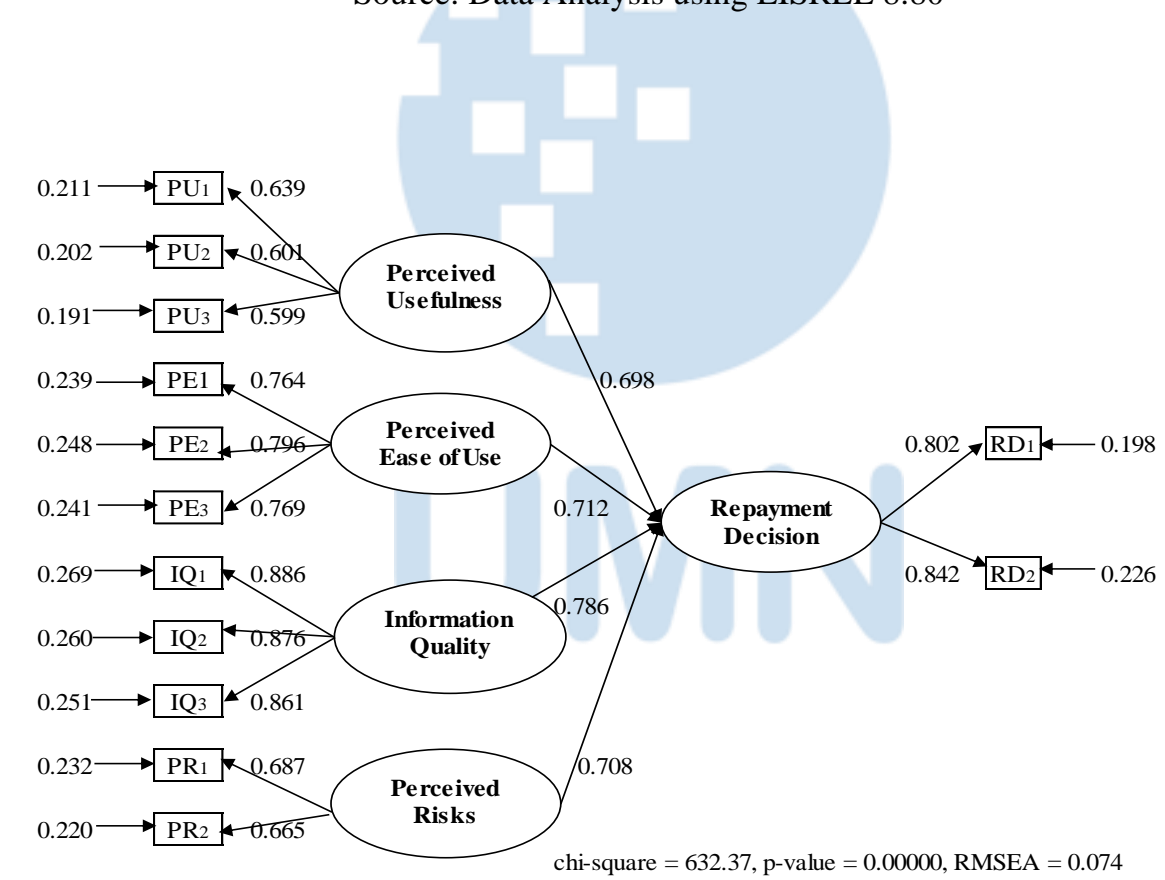
follow:

Meanwhile, the result of hypothesis testing using path diagram, could be explained as

\section{Figure 8. Structural Diagram (Standardized)}

Source: Researcher Data Analysis (2020) 


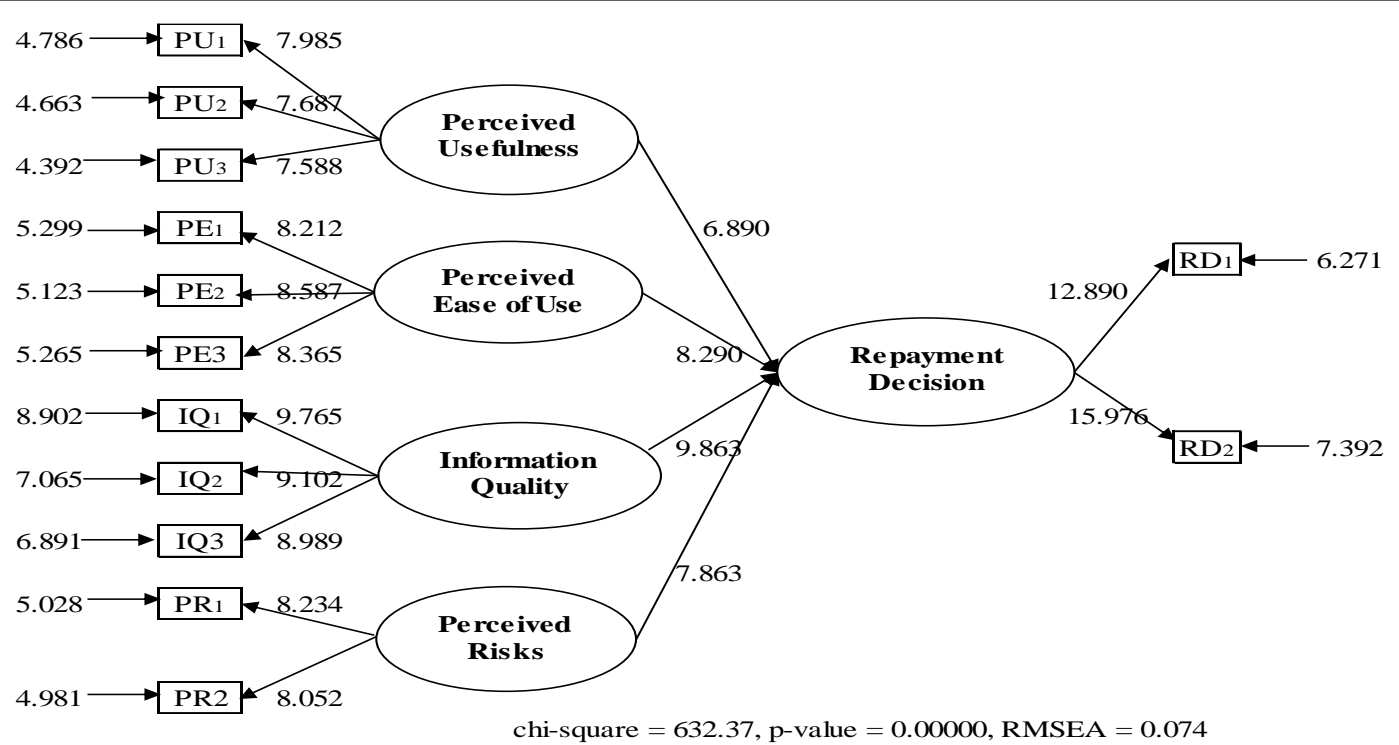

Figure 9. Structural Diagram (T-Value)

Source: Researcher Data Analysis (2020)

The result of hypotheses testing could be explained below:

Table 10. Result of Hypothesis Testing

\begin{tabular}{lllll}
\hline Hypotheses & Variables & $\begin{array}{l}\text { Coefficient } \\
\text { Standard }\end{array}$ & t-Value & $\begin{array}{l}\text { Statistical } \\
\text { Conclusion }\end{array}$ \\
\hline $\mathrm{H}_{1}$ & $\mathrm{PU} \rightarrow \mathrm{RD}$ & 0.698 & 6.890 & Data Supported \\
$\mathrm{H}_{2}$ & $\mathrm{PE} \rightarrow \mathrm{RD}$ & 0.712 & 8.290 & Data Supported \\
$\mathrm{H}_{3}$ & $\mathrm{IQ} \rightarrow \mathrm{RD}$ & 0.786 & 9.863 & Data Supported \\
$\mathrm{H}_{4}$ & $\mathrm{PR} \rightarrow \mathrm{RD}$ & 0.708 & 7.863 & Data Supported \\
\hline
\end{tabular}

The research able to create a structural equation model as follow:

$\mathrm{RD}=0.698 * \mathrm{PU}+0.712 * \mathrm{PE}+0.786 * \mathrm{IQ}+0.708 * \mathrm{PR}$, Errorvar $=0.43, \mathrm{R}^{2}=0.783$
$(0.040)$
$(0.050)$
(0.063)
$(0.048)$
6.890
8.290
9.863
7.863

The result of hypotheses testing could be explained further:

$\mathrm{H}_{1}$ : Perceived Usefulness had a positive effect on repayment decision, with the t-value $>2$ (6.890), with the effect value of 0.698 . The research showed that the repayment decision was influenced by the ability of the repayments apps in handling the transaction rapidly in more effective ways. This finding supported the previous research done by Lim (2003) who mentioned that borrower preferred to get more alternatives payment system using the advanced technology during the Covid 19 pandemic. Even the repayment apps could offered more simple way in settling the financial transaction, customers still considered other important factors such as: security protection and data privacy.

$\mathrm{H}_{2}$ : Perceived Ease of Use had also a positive effect on repayment decision, with the tvalue of 8.290 and the effect value of 0.712 . The result supported the previous research that mentioned that perceived ease of use had a significant effect into using the apps Khosravi and Hussin (2014). The previous research showed that perceived ease of use had a significant effect into attitude (Liébana-Cabanillas et al., 2018; Mwiya et al., 2017; Alarcon-del-Amo et al., 2014). The less effort in using the repayment apps would encourage the borrowe to use it more frequently (Shipps \& Phillips, 2013). If users found difficulties in accessing the digital platform, it would also influence their reluctant behaviour in adapting the new technology 
(Lim, 2003). The result of this research also aligned with the previous study of Chen (2014) who explained that one key success factor for the P2P lending platform to attract the users was the ability to provide the user interface (UI) and user experience design (UX). Most borrowers were willing to use the repayment apps if they felt that the apps were easy to use, flexible, simple and understandable.

$\mathrm{H}_{3}$ : Information quality had the highest and significant influence on customer decision to repay the loan in Indonesia's P2P lending platforms, with the t-value of 9.863 and the effect value of 0.786 . The borrower paid greater attention to all the information related with the current situation, included: the interest rate, the loan payment amount, the outstanding loan, the term and schedule of payment. The finding was supported to research by Chen et al. (2014) who explained that information quality had positive and significant effect to lenders' trust in making lending decisions.

$\mathrm{H}_{4}$ : Perceived Risk had a significant influence to repayment decision with the t-value of 7.863 and the effect value of 0.708 . The risk related with the repayment apps in P2P lending platform were security issues in using the apps. A higher safety protection level would increase the level of the repaying decision through a P2P lending platform. The result supported previous study that explained that the safety protection had significant effect in the P2P lending platform business (Chen et al., 2014; Meng, 2016). This finding aligned with the study of Lee et al. (2015) who mentioned that security guarantee was the major factor in the online payment system. The repayment apps in P2P lending platforms are a new concept in Indonesia financial business and there is an urgency for government to set-up a clear regulation to protect the interest of the borrowers in using the repayment apps especially during the Covid 19 pandemic. The finding also supported the research done by [2] who explained the secure platform would keep the secrecy of the borrowers.

\section{CONCLUSION}

Information quality had the highest effect in influencing borrower decision to repay their loan. Meanwhile, all the variables such as perceived usefulness, perceived ease of use and perceived security and risk free had positive impact in developing the borrower decision in using the repayment apps. The repayment application platform should develop innovation that focus more on user-friendly features and experiences using more understandable languages and symbols. Therefore, the researcher suggested that the Repayment apps had to provide interactive feature with more User Experience (UX) or User Interface (UI) design. The P2P lending platform had to maintain long relationship with the borrowers and ensure that they were able to develop an integrative system that could protect data security of their customers.

The R-square of this research showed the value of 0.783 . It meant that even all the independent variables had a positive impact in borrower decision to repay the loan with $78.3 \%$ effect, there might be other variables that could be considered to make the repayment apps more successfully implemented, such as: social networking and customer knowledge (Lim, 2003).

There're an urgency to encourage the support of the technology financial ecosystem, including the government in initiating a clear regulation to protect the stakeholders and in the same time had to deliver highest standard of service quality to attain firm competitiveness and performance (Meng, 2014). The succesful implementation of repayment apps as an alternatives for the borrower in repaying their loans would bring more benefit to P2P lending platform itself, such as: lowering the default rate and in the same time support the 
government mission to running the SME's business back to normal again in more speedy time.

\section{ACKNOWLEDGMENT}

The author would like to thank for the Kemenristek Dikti that funding support under the Contract No. 1778/HD-LPPM/UMN/IV/2021.

\section{REFERENCES}

Alarcon-del-Amo, M.-d.-C., Lorenzo-Romero, C., \& Chiappa, G. D. (2014). Adoption of Social Networking Sites by Italian. Information System E-Business Management, 12, 165187.

Bachmann, A., Becker, A., Buerkner, D., \& Hilker, M. (2011). Online Peer-to-Peer Lending - A Literature Review. Journal of Internet Banking and Commerce, 16 (2), 1-18.

Bhattacherjee, A. (2001). Understanding Information Systems Continuance: An Expectation-Confirmation Model. MIS Quarterly, 25(3), 351-370.

Blohm, I.; Leimeister, J. M. \& Krcmar, H. (2013). Crowdsourcing: How to Benefit from (Too) Many Great Ideas. MIS Quarterly Executive, Vol. 12, pp. 199-211.

Chawla, D., \& Joshi, H. (2018). Consumer Attitude and Intention to Adopt Mobile Wallet in India - An Empirical Study. International Journal of Bank Marketing, 12(3), 21-25.

Chen, D., \& Han, C. (2012). A Comparative Study of Online, P2P Lending in the USA and China, The Journal of Internet Banking and Commerce. 17 (2), 12-15.

Chen, D., Lai, F., \& Lin, Z. (2014). A trust Model for Online Peer-to-Peer Lending: A Lender's Perspective. Information Technology Management, 5(4), 239-254.

Cinca, S.C., Nieto, B.G., \& Palacios, L.L. (2015). Determinants of Default in P2P Lending. PloS One, 10 (10).

Cooper, D.R., \& Schindler, P. S. (2014). Business Research Methods. 10th ed. Singapore: McGraw-Hill.

Davis, F. D. (1989). Perceived Usefulness, Perceived Ease of Use, and User Acceptance of Information Technology. MIS Quarterly, 13(3), 319-340.

Egbunike, F.C., Emudainohwo, O.B., Gunardi, A., Kurniasari, F., Prihanto, J.J.N. (2018): Sustainability Accounting Practices and Disclosure by Multinational Corporation in Nigeria. Journal of Applied Economic Sciences, Vol. XIII, Summer, 3(57), pp. 751-759.

Eisingerich, A.B., \& Bell, S.J. (2008). Perceived Service Quality and Customer Trust Does Enhancing Customers' Service Knowledge Matter? Journal of Service Research, 10(3), 256-368.

Gebremedhin, K.T. (2010). Determinants of Successful Loan Repayment Performance of Private Borrowers in Development Bank of Ethiopia, North Region. African Journal of Agricultural and Resources Economics, 12(3), 257-270.

Gefen, D., Karahanna, E., \& Straub, D. (2003). Trust and TAM in Online Shopping: An Integrated Model. MIS Quarterly, 27(1), 51-90.

Khosravi and Hussin: A Review of Customer Knowledge Management Importance (2014). Journal of Soft Computing and Decision Support Systems. Vol.1 (1), pp. 45-52.

Kim, Y., Park, Y.-J., Cho, J., \& Yeon, J. (2015). An Empirical Study on The Adoption of "Fintech" Service: Focused on Mobile Payment Services. Advanced Science and Technology Letters, 114, 136-140. 
Kurniasari, F (2019). Buku Panduan Aplikasi the Worm. UMN Press.

Liebana-Cabanillas, F., Higueras-Castillo, E., Molinillo, S., \& Montanez, M. R. (2018). Assesing The Role of Risk and Trust in Customers' Adoption of Online Payment System. International Journal of Information Systems and Software Engineering for Big Companies, 99-113.

Lee, C.-Y., Tsao, C.-H., \& Chang, W.-C. (2015). The Relationship between Attitude toward Using and Customer Satisfaction with Mobile Application Services. Journal of Enterprise Information Management, 28(5), 680-697.

Lee, I., \& Shin, Y.J., Fintech: Ecosystem, Business Models, Investment Decision, and Challenges (2018). Business Horizons. Vol. 61, 35-46.

Li, Y., \& Huang, J.(2009). Applying Theory of Perceived Risk and Technology Acceptance Model in the Online Shopping Channel. World Academy of Science, Engineering and Technology. pp.9-12.

Lim, N.: Consumers' perceived risk: sources versus consequences (2003). Electronic Commerce Research and Applications, Vol. 2(3), pp. 216-228.

Lin, M., Prabhala, N., \& Viswanathan, S. (2009). Can Social Networks Help Mitigate Information Asymmetry in Online Markets? ICIS 2009 Proceedings, Paper 202.

Meng, F. (2016). What Determinants of Lending Decision for Chinese Peer-to-Peer Lenders? Profile of Finance Management, University of Twente, Faculty of Behavioral, Management and Social Sciences.

Mwiya, B., Chikumbi, F., Shikaputo, C., Kabala, E., Kaulung'ombe, B., \& Siachinji, B. (2017). Examining Factors Influencing E-Banking Adoption: Evidence from Bank Customers in Zambia. American Journal of Industrial and Business Management, 741-759.

Nunnaly, J.: Psychometric Theory. pp. 64-65 (1978) Gabbett, T., Jenkins, D., \& Abernethy, B. (2010). Physical collisions and injury during professional rugby league skills training. Journal of Science and Medicine in Sport, 13(6), 578-583. doi:10.1016/j.jsams.2010.03.007

Karlan, D. S., \& Zinman, J. (2012). List randomization for sensitive behavior: An application for measuring use of loan proceeds. Journal of Development Economics, 98(1), 71-75.

MacColl, F., Ker, I., Huband, A., Veith, G., \& Taylor, J. (2009, November 12-13). Minimising pedestrian-cyclist conflict on paths. Paper presented at the Seventh New Zealand Cycling Conference, New Plymouth, New Zealand. Retrieved from http://cyclingconf.org.nz/system/files/NZCyclingConf09_2A_MacColl_

PedCycleConflicts.pdf

Mann, D. L. (2010). Vision and expertise for interceptive actions in sport (Doctoral dissertation, The University of New South Wales, Sydney, Australia). Retrieved from http://handle.unsw.edu.au/1959.4/44704

Matthews, L. (2011, November 23). Foodbanks urge public to give generously. Manawatu Standard, p. 4.

Palmer, F. (2007). Treaty principles and Maori sport: Contemporary issues. In C. Collins \& S. Jackson (Eds.), Sport in Aotearoa/New Zealand society (2 ${ }^{\text {nd }}$ ed., pp. 307-334). South Melbourne, Australia: Thomson. 
Rogers, C. (2011, November 26). Smartphone could replace wallets. The Dominion Post. Retrieved from http://www.stuff.co.nz/technology/gadgets/6038621/Smartphone-couldreplace-wallets

Whitney, E., \& Rolfes, S. (2011). Understanding nutrition (12 ${ }^{\text {th }}$ ed.). Australia: Wadsworth Cengage Learning. 